\title{
Tandem affinity purification of functional TAP-tagged proteins from human cells
}

\author{
Juraj Gregan ${ }^{1,2}$, Christian G Riedel ${ }^{2}$, Mark Petronczki ${ }^{2}$, Lubos Cipak ${ }^{1}$, Cornelia Rumpf ${ }^{1}$, Ina Poser ${ }^{3}$, \\ Frank Buchholz ${ }^{3}$, Karl Mechtler ${ }^{2} \&$ Kim Nasmyth ${ }^{2,4}$
}

\begin{abstract}
${ }^{1}$ Department of Chromosome Biology, Max F. Perutz Laboratories, University of Vienna, Dr Bohr-Gasse 1, 1030 Vienna, Austria. ${ }^{2}$ Research Institute of Molecular Pathology, Dr Bohr-Gasse 7, 1030 Vienna, Austria. ${ }^{3}$ Max-Planck-Institute for Molecular Cell Biology and Genetics, Pfotenhauerstrasse 108, D-01307 Dresden, Germany. ${ }^{4}$ Department of Biochemistry, University of Oxford, South Parks Road, OX1 3QU Oxford, UK. Correspondence should be addressed to J.G. (juraj.gregan@univie.ac.at).
\end{abstract}

Published online 3 May 2007; doi:10.1038/nprot.2007.172

\begin{abstract}
Tandem affinity purification (TAP) is a generic two-step affinity purification protocol for isolation of TAP-tagged proteins together with associated proteins. We used bacterial artificial chromosome to heterologously express TAP-tagged murine Sgo1 protein in human HeLa cells. This allowed us to test the functionality of the Sgo1-TAP protein by RNA interference-mediated depletion of the endogenous human Sgo1. Here, we present an optimized protocol for purification of TAP-tagged Sgo1 protein as well as KIAA1387 from HeLa cells with detailed instructions. The purification protocol can be completed in 1 day and it should be applicable to other proteins.
\end{abstract}

\section{INTRODUCTION}

Most cellular processes are carried out by multiprotein complexes. The identification of individual subunits is essential for understanding their function. To streamline the purification of protein complexes from cells, the TAP protocol was developed ${ }^{1,2}$. It has been successfully applied to purify protein complexes from various organisms including bacteria, yeasts, plants as well as mammalian cells ${ }^{3-14}$. We used the TAP protocol to purify proteins associated with murine Sgol protein ${ }^{15}$.

It is important to confirm that tag addition does not significantly affect the function of the tagged protein. In model organisms such as yeast, functionality of tagged proteins can be easily tested. In mammalian cells, the lack of efficient homologous recombination makes the functionality test difficult. Kittler et al. ${ }^{16}$ demonstrated that expression of murine bacterial artificial chromosomes (BAC) in human cells provides a reliable method to create RNA interference (RNAi)-resistant tagged transgenes. In such cells, the endogenous human gene can be knocked down by RNAi, while the corresponding murine gene expressed from the integrated BAC resists the RNAi treatment. We expressed murine Sgol-TAP at physiological levels in HeLa cells from a BAC integrated into the HeLa genome ${ }^{15}$. This allowed us to determine whether the murine Sgo1-TAP was able to complement functionally the phenotype caused by depletion of the endogenous human Sgol. As a control we used HeLa cells expressing untagged murine Sgol from a BAC integrated into the HeLa genome. Depletion of Sgol in HeLa cells by RNAi leads to precocious separation of sister chromatids ${ }^{17,18}$. In contrast, in RNAi-treated cells expressing the murine SGO1-TAP transgene, the levels of precocious sister chromatid separation dropped considerably toward wild-type levels (Fig. 1). These results demonstrate that the murine Sgo1-TAP is functional in HeLa cells as the SGO1-TAP transgene prevented precocious separation of sister chromatids caused by depleting endogenous human Sgol by RNAi. Notably, the rescue of the RNAi phenotype of SGO1 by BAC transgenesis also confirms the specificity of the RNAi experiment ${ }^{17}$. In addition to HeLa cells described here, we have succeeded in generating BAC-transgenic U2OS cells with the same protocol (data not shown). Given the fact that other BAC-transgenic cell lines, including mouse ES cells, have been successfully generated, it is likely that BAC-transgenic clones can also be generated from many different cells. However, it is probable that for other cell lines, different transfection protocols have to be used for the delivery of the BAC DNA.

As an example of possible applications for this system, we used murine Sgol-TAP expressed from a BAC integrated into the HeLa genome to identify proteins that interact with Sgol in mitotic cells. Murine Sgo1-TAP, but not a control protein KIAA1387-TAP, associated with a specific form of protein phosphatase $2 \mathrm{~A}$ (Tables 1 and 2). This finding helped us to elucidate the mechanism by which Sgol protects centromeric cohesion ${ }^{15,19}$. Notably, endogenous human Sgol also associated with murine Sgo1-TAP, suggesting that Sgol proteins form homo-oligomers (Table 1). Thus, our protocol also allows detection of oligomer formation of the tagged protein.

Here, we describe an optimized TAP purification protocol with detailed instructions. We also describe our mass spectrometry (MS) protocol (Step 20A) and our SDS-polyacrylamide gel electrophoresis (SDS-PAGE) and silver staining protocol to visualize purified proteins (Step 20B; Fig. 2), which we have developed specifically for our target protein but could potentially be adapted for other proteins.

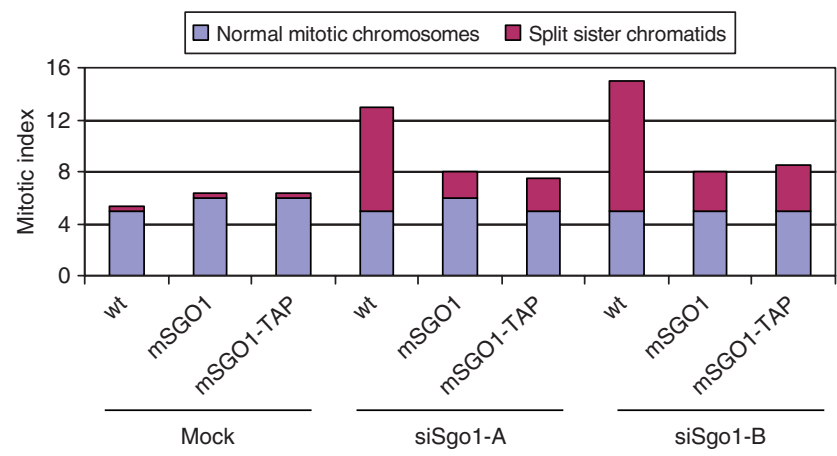

Figure 1 | Rescue experiment. Wild-type HeLa cells (wt) and BAC-transgenic HeLa cells expressing either murine SG01 (mSG01) or murine SG01-TAP (mSG01-TAP) were transfected with two different Sgo1 siRNAs (siSgo1-A, siSgo1-B) or deionized $\mathrm{H}_{2} \mathrm{O}$ (mock). Cells were examined by chromosome spreading followed by Giemsa staining and mitotic cells were classified into two categories based on chromosome configuration. 
PROTOCOL

\section{MATERIALS}

REAGENTS

-Sterile Millex syringe-driven filters (pore size: $0.45 \mu \mathrm{m}$ ) (Millipore)

- Sterile syringe $(20 \mathrm{ml})$

- Capillary (Pico Tip, FS360-20-10, New Objective)

- IgG sepharose beads (Amersham Biosciences)

- Calmodulin sepharose beads (Amersham Biosciences)

- Poly-prep chromatography columns (Bio-Rad)

-Separation column: $0.075 \mathrm{~mm}$ ID $\times 150 \mathrm{~mm}$ length, $3 \mu \mathrm{m}$ particle size

(Dionex, packed both)

- Protein molecular weight standard (e.g., Bio-Rad broad range)

$\cdot 4-12 \%$ (v/v) Bis-Tris gel (Invitrogen)

- Phosphate-buffered saline (PBS; Sigma)

- Calcium chloride (Sigma)

- Methanol (p.a.) (Sigma)

- Ethanol (p.a.) (Sigma)

- Acetic acid (Sigma)

- Formaldehyde (37\%; Sigma)

$\cdot \mathrm{NaCl}$ (Sigma)

$\cdot \mathrm{Na}_{2} \mathrm{~S}_{2} \mathrm{O}_{3}$ (Sigma)
- Deionized water

- Silver nitrate (Sigma)

- Sodium deoxycholate (Sigma)

- Trichloroacetic acid (Sigma)

- Tris (Sigma)

- Glycerol (Sigma)

- Magnesium acetate (Sigma)

- Imidazole (Sigma)

-NP-40 (Sigma)

- $\beta$-Mercaptoethanol (Sigma)

- Dithiothreitol (DTT; Sigma)

- AcTEV protease (Invitrogen)

- Ammonium bicarbonate (Sigma)

- Iodoacetamide (Sigma)

- Trypsin (Sigma)

- Acetonitrile (HPLC grade, Supra-Gradient, Biosolve B.V.)

- Water (HPLC grade, Supra-Gradient, Biosolve B.V.)

- $300 \mu \mathrm{m}$ ID $\times 5 \mathrm{~mm}$ length trap column cartridges (PepMap, C18, $5 \mu \mathrm{m}$ particle size, $100 \AA$ A pore size, Dionex)

TABLE 1 | List of proteins identified by mass spectrometry co-purifying with murine Sgo1-TAP.

\begin{tabular}{|c|c|c|c|}
\hline & Protein (GeneInfo identifier) & Description & Mascot score \\
\hline 1 & 32140473 & Protein kinase, catalytic polypeptide & 3087 \\
\hline 2 & 56205916 & Retinoblastoma-associated factor 600 (RBAF600) & 2523 \\
\hline 3 & 4506787 & IQ motif containing GTPase activating protein 1 & 2228 \\
\hline 5 & 231443 & Alpha isoform of scaffold subunit PR65 of PP2A & 909 \\
\hline 6 & 3603418 & Beta isoform of scaffold subunit of PP2A & 862 \\
\hline 7 & 46015216 & Chain F of Ef3-Cam complexed With Pmeapp & 803 \\
\hline 9 & 16507237 & Heat shock $70 \mathrm{kDa}$ protein 5 & 767 \\
\hline 10 & 17512093 & ATP-dependent DNA helicase II & 725 \\
\hline 11 & 54695922 & Beta isoform of catalytic subunit of PP2A & 699 \\
\hline 12 & 16303631 & Gamma isoform of regulatory subunit B56 of PP2A & 694 \\
\hline 13 & 47077243 & Unnamed protein product (similar to gamma isoform B56 of PP2A) & 668 \\
\hline 14 & 60302875 & Shugoshin-like 1 isoform A1/A2 & 631 \\
\hline 18 & 12654673 & Delta 2 isoform of regulatory subunit B56 of PP2A & 604 \\
\hline 19 & 38014029 & Retinoblastoma-associated factor 600 (RBAF600) & 598 \\
\hline 20 & 61680528 & Chain A, trapped intermediate of calmodulin & 575 \\
\hline 21 & 24308448 & Shugoshin-like 1 isoform $\mathrm{C} 1 / \mathrm{C} 2$ & 567 \\
\hline 22 & 18490282 & Alpha isoform of regulatory subunit B56 of PP2A & 559 \\
\hline 23 & 4529892 & HSP70-2 & 557 \\
\hline 24 & 68533509 & Myosin IE & 554 \\
\hline 25 & 66360504 & Chain T of Ef in complex with calmodulin & 540 \\
\hline 26 & 33286088 & Cullin 3 isoform & 531 \\
\hline 27 & 338695 & Beta-tubulin & 512 \\
\hline 28 & 18088719 & Beta-tubulin & 504 \\
\hline 29 & 37852 & Vimentin & 487 \\
\hline 37 & 20809886 & Tubulin, beta, 2 & 396 \\
\hline 38 & 188492 & Heat shock protein & 382 \\
\hline 39 & 340021 & Alpha-tubulin & 380 \\
\hline
\end{tabular}

Proteins associated specifically with Sgo1-TAP but not with KIAA1387-TAP are in bold. 
TABLE 2 | List of proteins identified by mass spectrometry co-purifying with murine KIAA1387-TAP.

\begin{tabular}{|c|c|c|c|}
\hline & $\begin{array}{l}\text { Protein (GeneInfo } \\
\text { identifier) }\end{array}$ & Description & $\begin{array}{l}\text { Mascot } \\
\text { score }\end{array}$ \\
\hline 1 & 61743954 & AHNAK nucleoprotein isoform 1 & 4657 \\
\hline 2 & 627367 & Desmyokin-human & 2665 \\
\hline 4 & 4506787 & IQ motif containing GTPase activating protein 1 & 2219 \\
\hline 5 & 13623235 & KIAA1387 protein (Mus musculus) & 2142 \\
\hline 6 & 34536452 & Unnamed protein product & 1831 \\
\hline 8 & 18028273 & Hypothetical protein SBBI57 & 1445 \\
\hline 9 & 346323 & Phosphoprotein phosphatase (EC 3.1.3.16) X catalytic chain & 1162 \\
\hline 10 & 20521049 & KIAA0432 & 1048 \\
\hline 11 & 16507237 & Heat shock 70 kDa protein 5 (glucose-regulated protein, 78 kDa) & 1027 \\
\hline 12 & 56205916 & Retinoblastoma-associated factor 600 (RBA600) & 928 \\
\hline 13 & 8250239 & Protein phosphatase 4 regulatory subunit 2 & 856 \\
\hline 17 & 46015216 & Chain F, crystal structure of the Ef3-Cam complex with Pmeapp & 655 \\
\hline 18 & 46852390 & Coiled-coil domain containing 6 & 609 \\
\hline 19 & 1346343 & Keratin, type II cytoskeletal 1 (cytokeratin 1) (K1) (CK 1) (67 kDa cytokeratin) (hair alpha protein) & 592 \\
\hline 20 & 535177 & AHNAK-related protein & 587 \\
\hline 21 & 292059 & MTHSP75 & 584 \\
\hline 22 & 66360504 & Chain $\mathrm{T}$, crystal structure of anthrax edema factor (Ef) in complex with calmodulin & 572 \\
\hline 23 & 28317 & Unnamed protein product & 524 \\
\hline 24 & 37852 & Vimentin & 513 \\
\hline 25 & 24899184 & KIAA2010 protein & 503 \\
\hline 26 & 181402 & Epidermal cytokeratin 2 & 491 \\
\hline 27 & 61680528 & Chain A, trapped intermediate of calmodulin & 490 \\
\hline 35 & 18645167 & Annexin A2, isoform & 320 \\
\hline 36 & 55957452 & Tripartite motif-containing 14 & 316 \\
\hline 37 & 435476 & Cytokeratin 9 & 299 \\
\hline 38 & 13528987 & Breast carcinoma amplified sequence 2 & 299 \\
\hline 39 & 16974825 & Chain $\mathrm{A}$, solution structure of calcium-calmodulin $\mathrm{N}$-terminal domain & 295 \\
\hline
\end{tabular}

Proteins associated specifically with KIAA1387-TAP but not with Sgo1-TAP are in bold.

- $5 \%$ acetonitrile (HPLC grade, Supra-Gradient, Biosolve B.V.)

$\cdot 0.1 \%$ formic acid (Fluka)

- $0.1 \%$ trifluoroacetic acid (TFA; Pierce)

EQUIPMENT

- Dounce homogenizers (Wheaton)

-Xcell SureLock Mini-Cell apparatus for SDS-PAGE (Invitrogen)

- Sterile roller bottles (BD Biosciences)

- Ion trap mass spectrometer (LTQ, Thermo Finnigan)

- Heated capillary (Pico Tip, FS360-20-10, New Objective)

- UltiMate nano HPLC system (NAN-75 Flow Splitter) (Dionex) operated

with Chromeleon chromatography software V 6.7 SP2 (Dionex)

Figure 2 | Purified proteins visualized by silver staining. Protein complexes associated with murine Sgo1-TAP and murine KIAA1386-TAP were isolated by tandem affinity purification, separated by SDS-PAGE and visualized by silver staining. Molecular weight marker (MW marker) is indicated on the left.

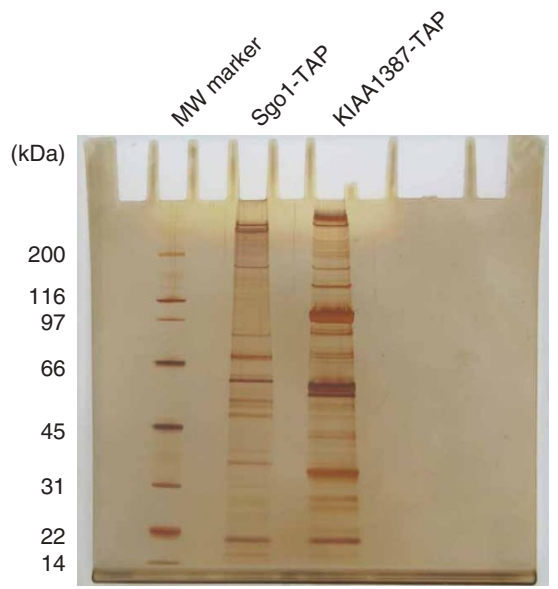


- $75 \mu \mathrm{m}$ ID $\times 150 \mathrm{~mm}$ length nano separation column (PepMap, C18, $3 \mu \mathrm{m}$ particle size, $100 \AA$ A pore size, Dionex)

- UltiMate separation system (NAN-75 Flow Splitter)

- Mascot (Matrix Science; version 2.1.0)

-Scaffold (version Scaffold-01_06_03, Proteome Software Inc.)

-MS requires expensive equipment and highly skilled personnel supplemented

by a well-established and integrated bioinformatic infrastructure

REAGENT SETUP

Media Prepare standard DMEM medium supplemented with $10 \%$ fetal calf serum, $0.2 \mathrm{mM} \mathrm{L-glutamine,} 100 \mathrm{U} \mathrm{ml}^{-1}$ penicillin and $100 \mu \mathrm{g} \mathrm{ml}^{-1}$ streptomycin.

Extraction buffer $50 \mathrm{mM}$ Tris $\mathrm{pH} 8.0,150 \mathrm{mM} \mathrm{NaCl}, 10 \%$ glycerol (v/v), $0.2 \%$ NP-40 (v/v), Complete Mini Protease Inhibitor (Roche) (1 tablet per $10 \mathrm{ml}$ ) and $1 \mathrm{mM}$ PMSF. $\triangle$ CRITICAL Add inhibitors just before use. Lysis buffer without inhibitors $50 \mathrm{mM}$ Tris $\mathrm{pH} 8.0,150 \mathrm{mM} \mathrm{NaCl}$, $10 \%$ glycerol (v/v) and $0.1 \%$ NP-40 (v/v).

Lysis buffer $50 \mathrm{mM}$ Tris $\mathrm{pH} 8.0,150 \mathrm{mM} \mathrm{NaCl}, 10 \%$ glycerol (v/v), $0.1 \%$ NP-40 (v/v), Complete Mini Protease Inhibitor (Roche) (1 tablet per $10 \mathrm{ml})$ and $1 \mathrm{mM}$ PMSF. $\triangle$ CRITICAL Add inhibitors just before use. TEV cleavage buffer $10 \mathrm{mM}$ Tris- $\mathrm{HCl} \mathrm{pH} 8.0,150 \mathrm{mM} \mathrm{NaCl}, 10 \%$ glycerol $(\mathrm{v} / \mathrm{v}), 0.1 \%$ NP-40 (v/v), $0.5 \mathrm{mM}$ EDTA and $1 \mathrm{mM}$ DTT. $\triangle$ CRITICAL Add DTT just before use.

Calmodulin binding buffer $10 \mathrm{mM} \beta$-mercaptoethanol, $10 \mathrm{mM}$ Tris- $\mathrm{HCl}$ $\mathrm{pH} 8.0,150 \mathrm{mM} \mathrm{NaCl}, 10 \%$ glycerol (v/v), 0.1\% NP-40 (v/v), $1 \mathrm{mM}$ imidazole, $1 \mathrm{mM} \mathrm{Mg}$-acetate and $2 \mathrm{mM} \mathrm{CaCl}_{2}$.

Calmodulin binding buffer-2 $1 \mathrm{mM} \beta$-mercaptoethanol, $10 \mathrm{mM}$ Tris- $\mathrm{HCl}$ $\mathrm{pH} 8.0,150 \mathrm{mM} \mathrm{NaCl}, 1 \mathrm{mM} \mathrm{Mg}$-acetate and $2 \mathrm{mM} \mathrm{CaCl}_{2}$.

Fixing solution $50 \%$ methanol $(\mathrm{v} / \mathrm{v}), 12 \%$ acetic acid $(\mathrm{v} / \mathrm{v})$ and $0.018 \%$ formaldehyde $(\mathrm{v} / \mathrm{v})$.

Silver nitrate solution $\quad 0.1 \%$ silver nitrate $(\mathrm{w} / \mathrm{v})$ and $0.027 \%$ formaldehyde $(\mathrm{v} / \mathrm{v})$ Developing solution $6 \%(\mathrm{w} / \mathrm{v})$ sodium carbonate, $0.00002 \% \mathrm{Na}_{2} \mathrm{~S}_{2} \mathrm{O}_{3}(\mathrm{w} / \mathrm{v})$ and $0.018 \%$ formaldehyde $(\mathrm{v} / \mathrm{v})$.

EQUIPMENT SETUP

HPLC-MS The UltiMate system consists of an UltiMate $\mu$ HPLC pump and a UV detection unit with the nano UV-Z View flow cell with $3 \mathrm{nl}$ cell volume, the Switchos $\mu$-column-switching device with loading pump and two 10-port valves, and the FAMOS $\mu$-autosampler equipped with the $250 \mu$ sample loop, $15 \mu \mathrm{l}$ injection needle and $250 \mu \mathrm{l}$ syringe (Large Volume Injection Kit). For FAMOS, use the $\mu \mathrm{L}$-Pickup injection method. As a transport liquid on FAMOS use $0.1 \%$ aqueous TFA (in Reagent Transport Vial 1). Use the $300 \mu \mathrm{m}$ ID $\times$ $5 \mathrm{~mm}$ length trap column cartridges for sample trapping and cleaning before separation. Operate the trap column at $20 \mu \mathrm{min}^{-1}$ on Switchos loading pump. As a separation column, use the $75 \mu \mathrm{m}$ ID $\times 150 \mathrm{~mm}$ length nano separation column. Operate the separation column at $275 \mathrm{nl} \mathrm{min}^{-1}$ on UltiMate separation system. Use the following tubing for separation: to deliver the flow from
Switchos to the FAMOS autosampler and to transport the sample to the trap column, use $130 \mu \mathrm{m}$ ID tubing. Keep the tubing length as short as possible. To connect the trap column to the Switchos valve, use the provided cartridge holder and two $30 \mu \mathrm{m}$ ID fused silica connections, which are delivered with the trap column. To make all flow paths used for nano flow $\left(275 \mathrm{nl} \mathrm{min}{ }^{-1}\right)$, use the $20 \mu \mathrm{m}$ ID PEEKSil connection tubing. To connect the UV cell output with the MS inlet, use $20 \mu \mathrm{m}$ ID fused silica and keep it as short as possible. Make all fluidic connections from Ultimate nano HPLC to the mass spectrometer using $20 \mu \mathrm{m}$ ID fused silica capillaries, connected with low dead-volume micro tight connectors from Dionex.

Use the following mobile phases for the separation column:

HPLC mobile phase A: 95\% water (HPLC grade), 5\% acetonitrile (HPLC grade) and $0.1 \%$ formic acid;

HPLC mobile phase B: $30 \%$ water, $70 \%$ acetonitrile and $0.1 \%$ formic acid. Use water with loading mobile phase for the Switchos: $0.1 \%$ TFA is a loading mobile phase for the Switchos.

For separation, use the following HPLC gradient:

\begin{tabular}{cc}
\hline Time (min) & $\%$ B \\
\hline $0-30$ & $0-50$ \\
$30-31$ & $50-100$ \\
$31-35$ & $100-0$ \\
$36-50$ & 0 \\
\hline
\end{tabular}

Use the following tubing for separation: to deliver the flow from Switchos to the FAMOS autosampler and to transport the sample to the trap column, use $130 \mu \mathrm{m}$ ID tubing. Keep the tubing length as short as possible. To connect the trap column to the Switchos valve, use the provided cartridge holder and two $30 \mu \mathrm{m}$ ID PEEKSil connections delivered with the trap column. To make all flow paths used for nano flow $\left(275 \mathrm{nl} \mathrm{min}^{-1}\right)$, use the $20 \mu \mathrm{m}$ ID PEEKSil connection tubing. To connect the UV cell output with the MS inlet, use 20 $\mu \mathrm{m}$ ID fused silica and keep it as short as possible.

Mass spectrometry Transfer the eluting peptides online to a heated capillary of an ion trap mass spectrometer. Use the following ESI parameters:

\begin{tabular}{ll}
\hline Spray voltage & $1.5 \mathrm{kV}$ \\
Capillary temperature & $200{ }^{\circ} \mathrm{C}$ \\
Capillary voltage & $26 \mathrm{~V}$ \\
Tube lens offset voltage & $95 \mathrm{~V}$ \\
Electron multiplier & $-800 \mathrm{~V}$ \\
Gain control & 20,000 \\
\hline
\end{tabular}

The collision energy is set automatically depending on the mass of the parent ion.

\section{PROCEDURE}

\section{Preparation of HeLa cell extract}

1| Grow 8 liters of HeLa-S3 cells in roller bottles with DMEM medium supplemented with $10 \%$ fetal calf serum, $0.2 \mathrm{mM}$ L-glutamine, $100 \mathrm{U} \mathrm{ml}^{-1}$ penicillin and $100 \mu \mathrm{g} \mathrm{m}^{-1}$ streptomycin to a density of about $1 \times 10^{6} \mathrm{cells}^{-1}$.

2| Pellet cells by centrifugation ( $500 \mathrm{~g}$ for $5 \mathrm{~min}$ at $4^{\circ} \mathrm{C}$ ) and discard the supernatant.

3| Wash the pellet by resuspending the cells with $100 \mathrm{ml}$ of ice-cold PBS gently by pipetting and repeating the centrifugation in Step 2. Repeat the wash once.

PAUSE POINT Cell pellets can be frozen in liquid nitrogen and stored at $-80{ }^{\circ} \mathrm{C}$ for several days.

4| Resuspend the cells in $200 \mathrm{ml}$ of ice-cold extraction buffer and transfer the cell suspension into the pre-chilled Dounce homogenizer.

5| Homogenize cells with 25 strokes in a Dounce homogenizer with a tight-fitting pestle and incubate on ice for 5 min; repeat the homogenization one more time.

6| Remove insoluble material by centrifugation at $13,000 \mathrm{~g}$ for $10 \mathrm{~min}$ at $4^{\circ} \mathrm{C}$ and keep the supernatant.

7| Centrifuge at $34,000 \mathrm{~g}$ for 20 min at $4{ }^{\circ} \mathrm{C}$ and keep the supernatant.

? TROUBLESHOOTING 
8| Filter the supernatant through a sterile Millex syringe-driven filter (pore size: $0.45 \mu \mathrm{m}$ ) at $4{ }^{\circ} \mathrm{C}$ and proceed directly to protein complex purification.

\section{? TROUBLESHOOTING}

\section{Protein complex purification}

9| Wash $500 \mu \mathrm{l}$ of IgG sepharose beads using a poly-prep chromatography column twice with $10 \mathrm{~mL}$ of lysis buffer at $4{ }^{\circ} \mathrm{C}$.

10| Add the cell extract from step 8 to washed IgG beads from step 9 and incubate for $2 \mathrm{~h}$ at $4{ }^{\circ} \mathrm{C}$ on a rotating wheel.

? TROUBLESHOOTING

11| Wash beads twice with $10 \mathrm{ml}$ of ice-cold lysis buffer at $4{ }^{\circ} \mathrm{C}$ (all washing steps are performed on poly-prep chromatography column).

12| Wash beads with $10 \mathrm{ml}$ of ice-cold lysis buffer without inhibitors at $4{ }^{\circ} \mathrm{C}$.

13| Wash beads with $10 \mathrm{ml}$ of ice-cold TEV cleavage buffer at $4{ }^{\circ} \mathrm{C}$.

14| Resuspend beads in $2 \mathrm{ml}$ of ice-cold TEV cleavage buffer and add $50 \mu \mathrm{l}$ of AcTEV protease (Invitrogen); incubate at $16{ }^{\circ} \mathrm{C}$ for $2 \mathrm{~h}$ (alternatively at $4^{\circ} \mathrm{C}$ for $16 \mathrm{~h}$ ) on a rotating wheel.

? TROUBLESHOOTING

15| Wash $70 \mu \mathrm{l}$ of calmodulin sepharose beads (Amersham Biosciences), using a column (Bio-Rad), twice with $10 \mathrm{ml}$ of calmodulin binding buffer at $4{ }^{\circ} \mathrm{C}$.

16| Collect the TEV eluate (flow-through) from step 14 and adjust $\mathrm{CaCl}_{2}$ to $3 \mathrm{mM}$ final concentration.

17| Add $6 \mathrm{ml}$ of calmodulin binding buffer to the TEV eluate and transfer to the washed calmodulin beads from Step 15 and incubate for $2 \mathrm{~h}$ at $4{ }^{\circ} \mathrm{C}$ on a rotating wheel.

18| Wash beads with $10 \mathrm{ml}$ of ice-cold calmodulin binding buffer at $4^{\circ} \mathrm{C}$.

19| Wash beads twice with $10 \mathrm{ml}$ of ice-cold calmodulin binding buffer-2 at $4{ }^{\circ} \mathrm{C}$.

20| Submit one half of the calmodulin beads for MS analysis (option A); use the remaining calmodulin beads for SDS-PAGE and silver staining (option B). If using option B, see also the protocol by Schagge ${ }^{20}$.

PAUSE POINT Calmodulin beads can be frozen in liquid nitrogen and stored at $-80{ }^{\circ} \mathrm{C}$ for several days.

$\triangle$ CRITICAL STEP While the conventional TAP protocol uses EGTA to elute proteins from calmodulin beads, we were not able to efficiently elute proteins from calmodulin beads by EGTA. To overcome this limitation, we directly submitted calmodulin beads to tryptic digestion followed by MS analysis and we boiled calmodulin beads in SDS buffer for the SDS-PAGE and silver staining analysis.

\section{(A) Tryptic digest, HPLC-MS/MS and database search}

(i) Tryptic digest: titrate the samples to $\mathrm{pH} 8.0$ by addition of $1.0 \mathrm{M} \mathrm{Tris-} \mathrm{HCl}, \mathrm{pH} 8.5$.

(ii) Wash calmodulin beads five times with $50 \mathrm{mM}$ ammonium bicarbonate and $50 \mathrm{mM}$ ammonium bicarbonate/30\% acetonitrile by centrifugation ( $500 \mathrm{~g}$ for $5 \mathrm{~min}$ at room temperature, i.e. $23^{\circ} \mathrm{C}$ ).

(iii) Reduce sample by incubation with $1 \mu \mathrm{g}$ of DTT for $1 \mathrm{~h}$ at $56{ }^{\circ} \mathrm{C}$.

(iv) Alkylate the sample by incubation with $5 \mu \mathrm{g}$ of iodoacetamide for $30 \mathrm{~min}$ at room temperature in the dark.

(v) Digest the proteins on beads with $200 \mathrm{ng}$ trypsin for $4 \mathrm{~h}$ at $37^{\circ} \mathrm{C}$ and then with an additional $200 \mathrm{ng}$ trypsin overnight.

(vi) Stop the digest by adding $10 \mu \mathrm{l}$ of $10 \%$ TFA. Use $2 \mu \mathrm{l}$ of the supernatant for MS analysis.

(vii) Perform nano HPLC separations using an UltiMate nano HPLC system (see EQUIPMENT SETUP).

(viii) Collect the data in the centroid mode using an MS experiment (see EQUIPMENT SETUP) (Full-MS) followed by four MS/MS experiments of the four most intensive ions (intensity at least 10,000). Use dynamic exclusion for data acquisition with exclusion duration of $1 \mathrm{~min}$ and an exclusion mass width of $\pm 3 \mathrm{Da}$. Make all fluidic connections from Ultimate nano HPLC to the mass spectrometer using $20 \mu \mathrm{m}$ ID fused silica capillaries, connected with low dead-volume micro tight connectors from Dionex.

(ix) Database search: extract tandem mass spectra using extract-msn delivered with Bioworks 3.3. Do not perform charge state deconvolution and deisotoping. Analyze MS/MS samples using Mascot (Matrix Science; version 2.1.0). Set up the Mascot to search the human_KBMS_5.0.20050304.fa database (187752 entries) assuming the digestion enzyme trypsin. Search the Mascot with a fragment ion mass tolerance of $0.60 \mathrm{Da}$ and a parent ion tolerance of $2.5 \mathrm{Da}$. Specify iodoacetamide derivative of cysteine in Mascot as a fixed modification. Specify oxidation of methionine in Mascot as a variable modification.

(x) Criteria for protein identification: use Scaffold (version Scaffold-01_06_03, Proteome Software Inc.) to validate MS/MS-based peptide and protein identifications. Accept peptide identifications if they can be established at greater 
PROTOCOL

than $95.0 \%$ probability as specified by the Peptide Prophet algorithm ${ }^{21}$. Accept protein identifications if they can be established at greater than $95.0 \%$ probability and contain at least two identified peptides. Assign protein probabilities by the Protein Prophet algorithm ${ }^{22}$. Group the proteins that contain similar peptides and cannot be differentiated based on MS/MS analysis alone to satisfy the principles of parsimony.

\section{(B) SDS-PAGE and silver staining}

(i) Run the protein samples on a $4-12 \%$ Bis-Tris gel (Invitrogen) according to the manufacturer's instructions.

(ii) Fix the gel by incubating for $1 \mathrm{~h}$ in $100 \mathrm{ml}$ of fixing solution.

(iii) Wash the gel for $10 \mathrm{~min}$ in $100 \mathrm{ml}$ of $50 \%(\mathrm{v} / \mathrm{v})$ ethanol.

(iv) Wash the gel for $10 \mathrm{~min}$ in $100 \mathrm{ml}$ of $30 \%(\mathrm{v} / \mathrm{v})$ ethanol.

(v) Sensitize the gel by incubating for $1 \mathrm{~min}$ in $100 \mathrm{ml}$ of $0.01 \%(\mathrm{w} / \mathrm{v}) \mathrm{Na}_{2} \mathrm{~S}_{2} \mathrm{O}_{3}$.

(vi) Wash the gel three times by incubating for $20 \mathrm{~s}$ in $100 \mathrm{ml}$ of deionized water.

(vii) Incubate the gel for $20 \mathrm{~min}$ in $100 \mathrm{ml}$ of silver nitrate solution.

(viii) Wash the gel three times by incubating for $20 \mathrm{~s}$ in $100 \mathrm{ml}$ of deionized water.

(ix) Incubate the gel in developing solution until protein bands become visible (1-10 min).

(x) Stop development by incubating the gel for $5 \mathrm{~min}$ in $100 \mathrm{ml}$ of $15 \%(\mathrm{v} / \mathrm{v})$ acetic acid.

(xi) Wash the gel twice with $100 \mathrm{ml}$ of deionized water.

\section{TIMING}

The protein complex purification protocol (Steps 2-20) can be completed in 1 day.

Step 1: growing HeLa cells, about 3 days

Steps 2 and 3: harvesting HeLa cells, $2 \mathrm{~h}$

Steps 4-20: protein complex purification, $11 \mathrm{~h}$

Step 20A(i)-(vi): tryptic digest, 1.5 days

Step 20A(vii) and (viii): nano HPLC and MS, $5 \mathrm{~h}$

Step 20A(ix): database search, $4 \mathrm{~h}$

Step 20B: SDS-PAGE and silver staining, $3 \mathrm{~h}$

\section{? TROUBLESHOOTING}

Troubleshooting advice can be found in Table 3.

TABLE 3 | Troubleshooting table.

\begin{tabular}{|c|c|c|c|}
\hline Step & Problem & Possible reason & Solution \\
\hline & Tagged protein is not functional & $\begin{array}{l}\text { Tag negatively interferes with protein's } \\
\text { function }\end{array}$ & $\begin{array}{l}\text { Test different constructs with the tag at the } \mathrm{N} \text { or } \\
\mathrm{C} \text { terminus. Insert a flexible oligopeptide linker } \\
\text { in between the tag and protein }\end{array}$ \\
\hline 7 & $\begin{array}{l}\text { Tagged protein is not present } \\
\text { in the supernatant }\end{array}$ & $\begin{array}{l}\text { Tagged protein is bound to membranes or } \\
\text { insoluble particles }\end{array}$ & Modify the preparation of cell extract \\
\hline $10-14$ & Degradation of proteins occurs & $\begin{array}{l}\text { HeLa cells were grown in plates and } \\
\text { harvested by trypsinization }\end{array}$ & Avoid using trypsin, harvest cells by scraping \\
\hline 14 & Degradation of proteins occurs & Presence of proteases in the sample & $\begin{array}{l}\text { Add protease inhibitors into TEV cleavage buffer } \\
\text { ( } 1 \text { tablet of Complete Mini Protease Inhibitor } \\
\text { (Roche) per } 20 \mathrm{ml}, 0.5 \mathrm{mM} \text { PMSF) }\end{array}$ \\
\hline
\end{tabular}

\section{ANTICIPATED RESULTS}

We developed this TAP protocol to optimize purification of proteins associated with mammalian Sgo $1^{15}$. Although each protein has unique properties, we believe that our TAP protocol should be applicable to other proteins. However, the functionality test of TAP-tagged murine transgenes is limited to those where human homologs can be identified. In some cases, artifactual binding partners may be identified owing to differences between human and mouse proteins. Although the conventional TAP tag has proven to be a very useful tool for protein complex purification, alternative affinity binding moieties are now available that may provide higher protein complex yield or allow for both protein isolation and live imaging of protein localization ${ }^{6,23}$. 
ACKNOWLEDGMENTS This work was supported by Boehringer Ingelheim and Austrian Science Fund (P18955-B03). Work in the Mechtler lab was supported by the Austrian Proteomics Platform (APP) within the Austrian Genome Program (GEN-AU) and by the Mitocheck project within the Sixth Framework Program of the European Commission. J.G. was a recipient of the EMBO long-term fellowship. We thank Tony Hyman for the gift of the TAP tagging cassette, and Laurence Pelletier and Ralf Kittler for help with Sgo1 tagging. We also thank members of Karl Mechtler lab for help with MS analysis and Jan Michael Peters and members of his lab for helpful discussions.

COMPETING INTERESTS STATEMENT The authors declare no competing financial interests.

Published online at http://www.natureprotocols.com

Rights and permissions information is available online at http://npg.nature.com/ reprintsandpermissions

1. Rigaut, G. et al. A generic protein purification method for protein complex characterization and proteome exploration. Nat. Biotechnol. 17, 1030-1032 (1999).

2. Puig, 0 . et al. The tandem affinity purification (TAP) method: a general procedure of protein complex purification. Methods 24, 218-229 (2001).

3. Gavin, A.C. et al. Functional organization of the yeast proteome by systematic analysis of protein complexes. Nature 415, 141-147 (2002).

4. Gavin, A.C. et al. Proteome survey reveals modularity of the yeast cell machinery. Nature 440, 631-636 (2006).

5. Butland, G. et al. Interaction network containing conserved and essential protein complexes in Escherichia coli. Nature 433, 531-537 (2005).

6. Burckstummer, T. et al. An efficient tandem affinity purification procedure for interaction proteomics in mammalian cells. Nat. Methods 3, 1013-1019 (2006).

7. Rohila, J.S., Chen, M., Cerny, R. \& Fromm, M.E. Improved tandem affinity purification tag and methods for isolation of protein heterocomplexes from plants. Plant J. 38, 172-181 (2004).

8. Bouwmeester, T. et al. A physical and functional map of the human TNF-alpha/ NF-kappa B signal transduction pathway. Nat. Cell Biol. 6, 97-105 (2004).

9. Gould, K.L., Ren, L., Feoktistova, A.S., Jennings, J.L. \& Link, A.J. Tandem affinity purification and identification of protein complex components. Methods 33, 239-244 (2004).
10. Forler, D. et al. An efficient protein complex purification method for functional proteomics in higher eukaryotes. Nat. Biotechnol. 21, 89-92 (2003).

11. Chen, C.Y. et al. AU binding proteins recruit the exosome to degrade ARE-containing mRNAs. Cell 107, 451-464 (2001).

12. Gully, D., Moinier, D., Loiseau, L. \& Bouveret, E. New partners of acyl carrier protein detected in Escherichia coli by tandem affinity purification. FEBS Lett. 548, 90-96 (2003)

13. Ishizuka, A., Siomi, M.C. \& Siomi, H. A Drosophila fragile $X$ protein interacts with components of RNAi and ribosomal proteins. Genes Dev. 16, 2497-2508 (2002).

14. Krogan, N.J. et al. Global landscape of protein complexes in the yeast Saccharomyces cerevisiae. Nature 440, 637-643 (2006).

15. Riedel, C.G. et al. Protein phosphatase $2 \mathrm{~A}$ protects centromeric sister chromatid cohesion during meiosis I. Nature 441, 53-61 (2006).

16. Kittler, R. et al. RNA interference rescue by bacterial artificial chromosome transgenesis in mammalian tissue culture cells. Proc. Natl. Acad. Sci. USA 102, 2396-2401 (2005).

17. McGuinness, B.E., Hirota, T., Kudo, N.R., Peters, J.M. \& Nasmyth, K. Shugoshin prevents dissociation of cohesin from centromeres during mitosis in vertebrate cells. PLoS Biol. 3, e86 (2005).

18. Kitajima, T.S., Hauf, S., Ohsugi, M., Yamamoto, T. \& Watanabe, Y. Human Bub1 defines the persistent cohesion site along the mitotic chromosome by affecting Shugoshin localization. Curr. Biol. 15, 353-359 (2005).

19. Kittler, R. et al. An endoribonuclease-prepared siRNA screen in human cells identifies genes essential for cell division. Nature 432, 1036-1040 (2004).

20. Schagger, H. Tricine-SDS-PAGE. Nat. Protocols 1, 16-22 (2006).

21. Keller, A., Nesvizhskii, A.I., Kolker, E. \& Aebersold, R. Empirical statistical model to estimate the accuracy of peptide identifications made by MS/MS and database search. Anal. Chem. 74, 5383-5392 (2002).

22. Nesvizhskii, A.I., Keller, A., Kolker, E. \& Aebersold, R. A statistical model for identifying proteins by tandem mass spectrometry. Anal. Chem. 75, 4646-4658 (2003).

23. Cheeseman, I.M. \& Desai, A. A combined approach for the localization and tandem affinity purification of protein complexes from metazoans. SCi. STKE 2005, pl1 (2005). 